\title{
EDUCATIONAL FUNCTION OF A NURSE CONCERNING NUTRITION OF PATIENTS WITH INTESTINAL STOMA
}

\author{
Jolanta Glińska, Anna Iszczek, Ryszard Markert, Beata Brosowska, Małgorzata \\ Lewandowska
}

Medical University of Łódź. Students' Scientific Circle at Chair of Nursing Education, Poland

\section{Summary}

Introduction: The continuous growth of number of people with stoma raises fears about their present and future quality of life. The creation of abdominal anus disturbs to a certain extent the functioning of alimentary tract. Keeping a good state of the nutrition of the stoma patients requires education of the patient as far as the knowledge of absorption and digestion processes in the alimentary tract are concerned. The diet after performing stoma should delivers necessary nutrients and should not cause symptoms like: diarrhoea, flatulence and constipation. The important thing is good toleration of taking nutrients by organism in order that they do not cause unpleasant symptoms. The necessity of solving this problem should be a priority for the whole therapeutic team and especially for the nursing personnel. To a large extent, it depends on the nurse, what kind of information and how it is passed on to the patient so that he can change his lifestyle.

The purpose of the study: The assessment of the educational function of a nurse in nutrition of patients with intestinal stoma and estimation of the respondents' level of knowledge on the rules of nutrition.

Method: The research was carried out in Lódź, in 2008. The research covered 103 patients with intestinal stoma. In this study, the method of diagnostic questionnaire was used - the questionnaire of our own construction was used. The verification of results was obtained by using nonparametric tests and contingency indicators.

Results: In spite of the negative influence of the disease and its treatment on patients, the presented data suggests that most patients feed on reasonably. Among the respondents $75 \%$ introduce new products in their diet gradually observing simultaneously the react of digestive system. Consumption of fruits and vegetables at least one a week was declared by $92 \%$ patients and $57 \%$ intake them every day. Satisfying is also the frequent of applying in the patients' diet fishes (68\%), dairy products $(66 \%)$ and products which contain much fibre $(72 \%)$. According to the rules of appropriate nutrition the patients intake right amount of liquids. Only some patients - around $25 \%$ - make nutritional mistakes using spicy spices to prepare meals (24\%), drinking sparkling beverages (20\%) and having too fat meals $(25 \%)$. The study has shown the essential statistical dependence between education of the patients and their way of nutrition. It was proven that $59,4 \%$ of respondents were informed by a nurse about the rules of the appropriate nutrition. The changes in this field show a growing tendency that is an effect of the education of the patient by a nurse. The study suggests that a larger emphasis should be put on the education of the patients in the field of colostomy irrigation. The patients should be also learn to do colostomy irrigation apart from the appropriate nutrition. Unfortunately only $19 \%$ respondents were trained in this range.

Key words: education - nutrition - intestinal stoma - nurse

\section{Introduction}

Together with the growth of prosperity, there has come some unfavourable changes of lifestyle and the real epidemic of our times has become chronic civilisation diseases. Most of them were considered as directly connected with inappropriate nutrition. One of them is colorectal carcinoma, which is the most fre- 
quent indication to perform stoma. The number of stomas performed grows in Poland every year. It becomes very often the necessity and also a procedure that can save life. Stoma gives new challenges and requirements. The patient must often modify his lifestyle; he must learn how to live with dysfunctions that were brought by the illness and operation. Very important aspect is nutrition which is one of the basic biological needs of every human being. In order to keep up the appropriate state of nutrition of the patients with stoma it requires the knowledge of absorption and digestion processes in the digestive system. The nutrition of patients with intestinal stoma depends on the level of fistula, primary disease and a state of nutrition before the operation. It requires a diet which is specifically modified because as a result of intestine resection the area of food absorption becomes smaller. The consequences of the removal of particular fragments of the alimentary tract are presented in the chart below.

\begin{tabular}{ll}
\hline Level of stoma & Disorders \\
\hline Sigmoid colon & No disorders, normal nutrition \\
Transverse colon & Periodic diarrhoea \\
Ileostomy & $\begin{array}{l}\text { Loss of water, electrolytes and nutritional } \\
\text { components }\end{array}$ \\
$\begin{array}{l}\text { Jejunostomy leaving } \\
<70 \text { cm of jejunum }\end{array}$ & Parenteral and enteral nutrition necessary \\
\hline
\end{tabular}

Very important metabolic processes take place in the large intestine, $20 \%$ of all energy that comes from digestion and food absorption is being produced. Here, also occur the processes of bacterial fermentation and in the end the stool is being formed. In contrast with the small intestine, the large intestine is not indispensable to live.

Nursing environment can play a particular role in the education of the patient.

It is very important that the nurse informs a patient about the rules of the appropriate nutrition and also about the avoidance of products that can disturb the functioning of the alimentary tract.

The purpose of the study: The assessment of the educational function of a nurse in nutrition of patients with intestinal stoma as well as the estimation of the respondents' level of knowledge on the rules of nutrition.

\section{Methodology of the research}

The method of diagnostic opinion poll was used to assess the level of knowledge of the patients and the educational function of a nurse, which constituted a questionnaire constructed for the needs of this study. The research was carried out in Polish Mother's Memorial Hospi- tal in Lódź, in 2008 during the training organised for the patients with stoma by Polish Society of Care over the Patients with Stoma / POLILKO/ and a company CONVATEC within the framework of the programme ,Spotkajmy się"("Let's meet"). The questionnaires were filled in by 106 respondents from Lódź region. The obtained results were analysed using the nonparametric tests: Test $\mathrm{c}^{2}$ with Yates correction. To analyse the strength of the association, Pearson and V-Cramer contingency indicators were used. The value of $p<0,05$ was assumed as a statistically important level.

\section{The results of the research}

The research was performed on 106 patients after the operation of stoma. Among the respondents the majority were men who constituted $53 \%$ of respondents. Most of the respondents were over 60 years old which made $67 \%$. Around $31 \%$ of respondents were the people between 40 and 60 years of age and only 2\% were the people between 20 and 40 . In the researched group, $47 \%$ were the patients that had stoma operation less than 5 years ago. The patients that had an operation 6 to 10 years ago made $28 \%$, and the ones that had it over 10 
years ago $-25 \%$. The prevalent group was formed by patients with colostomy $-81 \%$.
In the further part of this study, the level of knowledge of the patients on the reasonable nutrition after stoma operation was analysed.

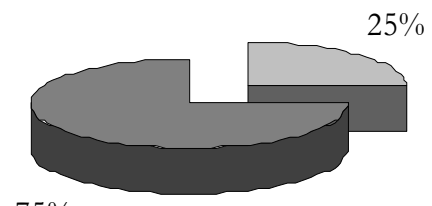

$$
\begin{aligned}
& \square \text { at once } \\
& \square \text { gradually }
\end{aligned}
$$

$75 \%$

\section{Drawing 1. Diet extension}

As we can see from the respondents' answers, $25 \%$ of respondents introduces new products to the menu at once, whereas $75 \%$ - does that gradually, observing the reaction of the alimentary tract.

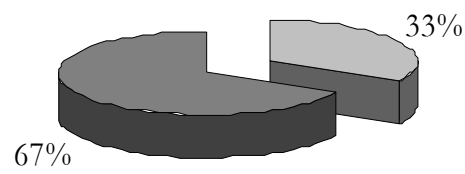

\author{
$\square$ 2-3 times \\ $\square$ 4-5 times
}

Drawing 2. The frequency of having meals

It can be vividly seen that $67 \%$ of respondents has meals $4-5$ times a day. However, alarming is the fact that $33 \%$ of patients has them too rarely, only 2-3 times a day. 


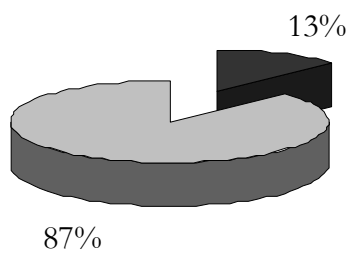

abundantly

$\square$ in small quantities

Drawing 3. The size of meals

The considerable majority of the questioned $87 \%$ - abides the rules of appropriate nutrition having meals in small amounts. But $13 \%$ of patients consume them abundantly.

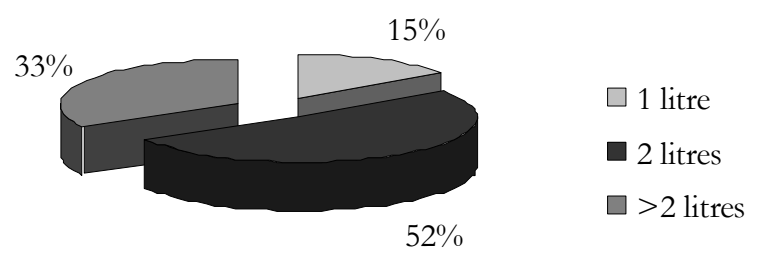

\section{Drawing 4. The quantity of liquids drunk}

The results are satisfactory because $85 \%$ of the questioned drinks not less than 2 litres of liquids during the day and only $15 \%$ of patients drinks too little liquids. The patients with stoma should not drink sparkling beverages and that was the answer of $80 \%$ of respondents. However, $20 \%$ of respondents admits that they drink sparkling beverages.

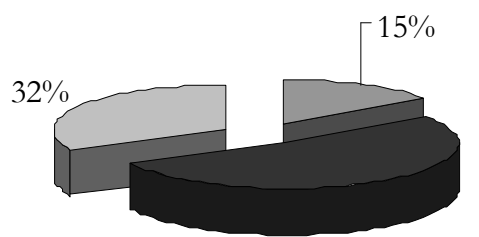

$\square$ twice a week

$\square$ once a weerk

$53 \%$ 


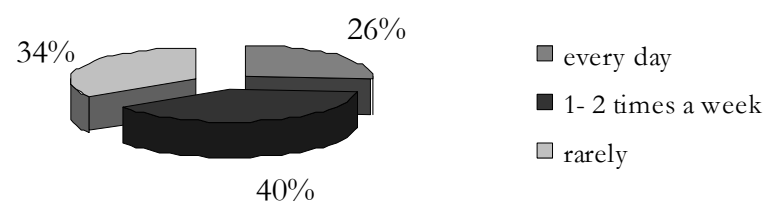

Drawing 5. The frequency of yoghurt consumption.

From the survey we can see that $68 \%$ of respondents consumes fish at least once a week, whereas $32 \%$ of the questioned - more rarely. Among the questioned $66 \%$ of respondents answered that they consume yoghurts at least once a week, including $26 \%$ - every day, whereas $34 \%$ - more rarely. Among the respondents fresh milk is drunk by $67 \%$, out of this $31 \%$ has problems with alimentary tract in the form of diarrhoea and flatulence after drinking milk.

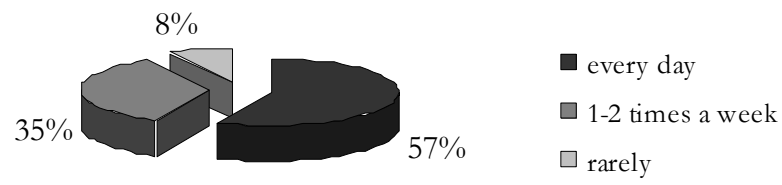

Drawing 6. The frequency of eating fruit and vegetables

The answers to the question concerning eating fruit and vegetables have shown that $92 \%$ of respondents eats them at least once a week. However, $8 \%$ of respondents claims that they seldom eat them. Among the respondents, the considerable majority $(72 \%)$ said that they eat products rich in fibre.
The results simply show that $76 \%$ of the questioned does not use spicy spices for the meals but the rest, i.e. $(24 \%)$ likes spicy food.

Having fat meals declares $25 \%$ of the respondents.

In the further part of the study, the education of patients concerning the nutrition after having intestinal stoma was examined.

\begin{tabular}{|c|c|c|c|c|c|c|}
\hline \multirow[b]{2}{*}{ The way of nutrition } & \multicolumn{3}{|c|}{$\begin{array}{l}\text { Education from the nurse side } \\
\text { Yes }\end{array}$} & \multirow{2}{*}{$\begin{array}{l}\text { No } \\
\text { Number of } \\
\text { respondents }\end{array}$} & \multicolumn{2}{|c|}{ Altogether } \\
\hline & $\begin{array}{l}\text { Number of } \\
\text { respondents }\end{array}$ & $\begin{array}{c}\text { structure } \\
\text { indicator } \\
\text { W [\%] }\end{array}$ & & & $\begin{array}{l}\text { structure } \\
\text { indicator } \\
\mathrm{W}[\%]\end{array}$ & \\
\hline Appropriate & 34 & 53,97 & 9 & 20,94 & 43 & 40,56 \\
\hline Partial & 11 & 17,46 & 17 & 39,53 & 28 & 26,41 \\
\hline Inappropriate & 18 & 28,57 & 17 & 39,53 & 35 & 33,03 \\
\hline Together & 63 & 100,00 & 43 & 100,00 & 106 & 100,00 \\
\hline Statistical analysis & \multicolumn{6}{|c|}{$\begin{array}{l}\text { Test } \mathrm{Chi}^{2} \text { Pearson }=13,23 \mathrm{p}<0,01 ; \quad \text { Test } \mathrm{Chi}^{2} \mathrm{NW}=13,77 \mathrm{p}<0,01 \\
\text { Indicator } \mathrm{V}_{\text {Cramer }}=0,37 ; \quad \text { Indicator } \mathrm{C}_{\text {Pearson }}=0,37\end{array}$} \\
\hline
\end{tabular}


The obtained results unanimously show a strong dependence between education from the side of the nursing personnel and reasonable nutrition. Over a half of the respondents $(54 \%)$ educated by nurses pays attention to the rules of nutrition after the exposure of intestinal stoma. These patients also to a smaller extent report such ailments as diarrhoea and constipation.

The patient's preparation to colostomy irrigation was also taken under analysis. Only $19 \%$ of respondents was trained in this area as we can see from the answers given.

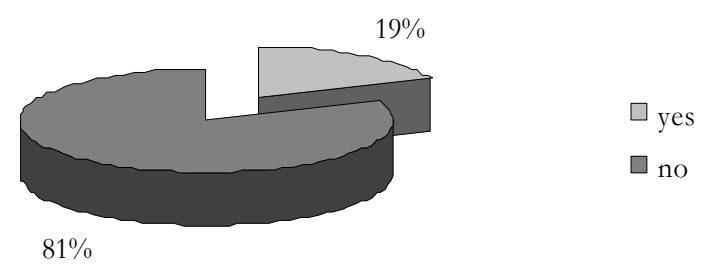

Drawing 7 . The educational function of a nurse concerning colostomy irrigation

\section{Discussion}

One of the most important dietetic aims in people with exposed intestinal stoma no matter its type is a regulation of the cycle of moving one's bowels so that there is no diarrhoea or constipation. People with exposed stoma should abide the same rules of nutrition which were fixed for healthy people. Most of the patients with stoma can eat and drink the same things as the ones before the operation. It should be, however, remembered that the diet must be light, healthy and diverse. The meals should be fresh, diverse and eaten on the regular basis in the intervals, 3 or 4 times a day and also at similar times. The ingredients of the diet must be well tolerated by the organism and cannot cause unpleasant ailments, that is why the new products should be gradually introduced and the reaction of the organism should be observed. The considerable part of the population re- searched (75\%) knows and respects these rules, introducing these products to the menu gradually and observing the behaviour of the alimentary tract. Very important is also the frequency of having meals. From the questionnaire, it can be seen that $67 \%$ of respondents has meals $4-5$ times a day. Very alarming seems the fact that $33 \%$ of patients has meals very rarely -2 or 3 times a day. Very satisfying are the results as far as the frequency of eating fish $(68 \%)$, dairy products $(66 \%)$, fruit and vegetables $(92 \%)$ and products rich in fibre $(72 \%)$ is concerned. Taking into account the fact that higher percentage of the patients with stoma are older people, in this diet a particular attention should be paid to drinking fresh milk which is very badly tolerated in these patients, because of the lack of the enzyme etching lactose. As our research show over a half of the patients drink fresh milk, out of whose $31 \%$ feels flatulence 
and has diarrhoea afterwards. The patients tolerate very well all fermentative products (yoghurts, buttermilk, kefirs, sour milk). One of the basic nutritious recommendations for people with stoma is supplying the organism with the water it looses. It is considered a minimum, 8 to 10 glasses of liquids, drunk on regular basis during the day. It should be remembered that loss of water is considerably higher in the state of disease, such as diarrhoea or fever. Also more water is lost by the organism during physical effort and during heat waves. Older people should drink at least 1,5-2 litres of liquids daily, even if they are not thirsty. People with heart failure should not exaggerate with the liquids drunk because of the risk of its intensity. The most recommended liquids for the people having stoma are: still mineral water, tea without sugar, vegetable juices e.g. tomato, carrot, beetroot etc. Patients with stoma should completely eliminate sweet and sparkling beverages e.g. fizzy drinks, coca cola as well as juices pasteurized because they contain high number of preservatives and can cause flatulence, diarrhoea or problems with stomach and intestines. The results of our research are satisfactory because up to $85 \%$ of respondents drinks at least 2 litres of liquids and only $15 \%$ of patients drinks too little liquids. Not many patients makes nutrition mistakes using spicy spices to prepare meals $(24 \%)$, drinking sparkling beverages $(20 \%)$ and having fat meals $(25 \%)$.

On the basis of the research it was shown that $59,4 \%$ of respondents was informed by a nurse on the rules of appropriate nutrition. These statements can be understood that the scope of the contents reported has important influence on the way the patients eat. An important statistical dependence was shown here $\mathrm{p}<0,01$. It depends to a large extent on a nurse what kind of information and how the information is transmitted so that the patient can change his lifestyle.
The patients with colostomy, apart from reasonable nutrition should also bring under control the ability of performing colostomy irrigation. For many years there was no unanimous opinion as far as the relevance of its performance is concerned. We can meet the supporters and opponents of the irrigation. However, many researchers emphasise its superiority over independent defecation and they agree that the patient should be informed how and when it can be performed. Today we know that colostomy irrigation enables to control the functioning of intestines and defecation and also limits the number of unpleasant smells and gases excreted. Unfortunately, among the respondents the considerable number of patients $(81 \%)$ was not trained in the scope of irrigation performance. On the basis of the material obtained we can formulate a suggestion that colostomy irrigation should be widely propagated.

\section{Results}

An important statistical dependence was recognized between the education of patients by a nurse and the way of nutrition. Presented research show that the most of patients eat in reasonable way.

\section{LITERATURE}

SZCZYGIEE, B.: Podstawy fizjologiczne żywienia chorych ze stomia. Troska, 2002; $3 ; 6$.

KOZŁOWSKA - WOJCIECHOWSKA, M.: Zasady żywienia pacjentów ze stomiq. Troska 2002, p. 7-8.

KOZŁOWSKA - WOJCIECHOWSKA, M.: Zasady żywienia pacjentów ze stomią. Część I. Troska 2005, 4; 3 OWEN, M. J., HOLMES, C. A.: Holism in the discourse of nursing. J. Adv. Nurs., 1993. Vol. 18, p. 1688-1695.

OLSZEWSKA, A.: Pielęgniarka - edukator. Pielęgniarka i położna, 2000, 3, 17.

KOPER, A., KAŹMIERCZAK, B., WARSZAWSKA, E.: Jakość życia chorych $\mathrm{z}$ nowotworem jelita grubego. Magazyn Pielegniarki i Położnej, 2000. Vol. 11, p. 16-17. 